\title{
Case Report: Primary dural based diffuse large B-Cell lymphoma in a 14 year-old boy [version 1; peer review: 2
}

\section{approved]}

\author{
Sunil Munakomi (i), Binod Bhattarai, Balaji Srinivas, Iype Cherian (iD \\ International Society for Medical Education, College of Medical Sciences, Bharatpur, Chitwan, 44207, Nepal
}

V1 First published: 25 Mar 2015, 4:78

https://doi.org/10.12688/f1000research.6269.1

Latest published: 25 Mar 2015, 4:78

https://doi.org/10.12688/f1000research.6269.1

\section{Abstract}

Primary dural lymphoma is a subentity of primary leptomeningeal lymphoma which represents $0.1 \%$ of all non-Hodgkin's lymphomas. Only five cases have been reported so far. We report a very rare case of primary dural-based lymphoma in a 14 year-old boy presenting with mass effect. The patient was managed with excision of the lesion and removal of the involved bone. Post-operatively, the patient showed good recovery. He was then referred to the oncology unit for further chemo- and radiation therapy. A high index of suspicion should therefore be kept in order to diagnose the condition in a timely fashion and then plan for appropriate management since diffuse large cell lymphoma has a relatively benign clinical prognosis.

\section{Keywords}

Surgical Resection, Primary dural diffuse large B-cell lymphoma, Paediatric cancer, Herniation syndrome, Intracranial lymphoma

\section{Open Peer Review}

Approval Status

1

2

version 1

25 Mar 2015

view

1. Guo-Yi Gao, Shanghai Institute of Head

Trauma, Shanghai, China

2. Amit Thapa (iD, Kathmandu Medical College, Kathmandu, Nepal

Any reports and responses or comments on the article can be found at the end of the article.

Corresponding author: Sunil Munakomi (sunilmunakomi@gmail.com)

Competing interests: No competing interests were disclosed.

Grant information: The author(s) declared that no grants were involved in supporting this work.

Copyright: $\odot 2015$ Munakomi S et al. This is an open access article distributed under the terms of the Creative Commons Attribution License, which permits unrestricted use, distribution, and reproduction in any medium, provided the original work is properly cited. Data associated with the article are available under the terms of the Creative Commons Zero "No rights reserved" data waiver (CC0 1.0 Public domain dedication).

How to cite this article: Munakomi S, Bhattarai B, Srinivas B and Cherian I. Case Report: Primary dural based diffuse large B-Cell lymphoma in a 14 year-old boy [version 1; peer review: 2 approved] F1000Research 2015, 4:78

https://doi.org/10.12688/f1000research.6269.1

First published: 25 Mar 2015, 4:78 https://doi.org/10.12688/f1000research.6269.1 


\section{Introduction}

Primary dural diffuse large B-cell lymphoma (DLBCL) is an extremely rare entity with only five cases reported so far ${ }^{1}$. The symptoms are nonspecific. The main differential diagnosis of the condition remains meningioma ${ }^{2}$. Currently there is no standard treatment due to a paucity of cases ${ }^{3}$. A high index of suspicion should be kept in order to diagnose the condition in a timely fashion and then plan for appropriate management since diffuse large cell lymphoma has a relatively benign clinical prognosis ${ }^{4}$. Here we report a case of a primary dural based DLBCL in a 14 year-old boy presenting with herniation syndrome, who improved after surgical excision and is currently on chemotherapy.

\section{Case report}

A 14 year-old Tharu boy, from Siraha (a remote village in Nepal) presented to our emergency department with a sudden onset altered sensorium which lasted for 1 day. The patient had a history of intermittent headaches and vomiting over the last 3 months. The patient's parents also noticed significant weight loss and the presence of scalp swelling for the last 2 months. There was no remarkable family history. Previous treatment history revealed that the patient had been taken to India 1 month back, where fine needle aspiration cytology (FNAC) of the scalp lesion in the parietal region had revealed Non-Hodgkin's lymphoma. The patient party was told the prognosis and advised for chemo- and radiation therapy but this was refused because of their poor financial status and so the family returned back to Nepal.

On initial examination at our ER room, the patient attained a Glasgow Coma Scale (GCS) of E2M4V2 with anisocoria on the left side. There were two scalp swellings on the left parietal and the frontal regions (Figure 1) which were soft and fluctuant. Serology performed was negative for human immuno-deficiency virus (HIV) and

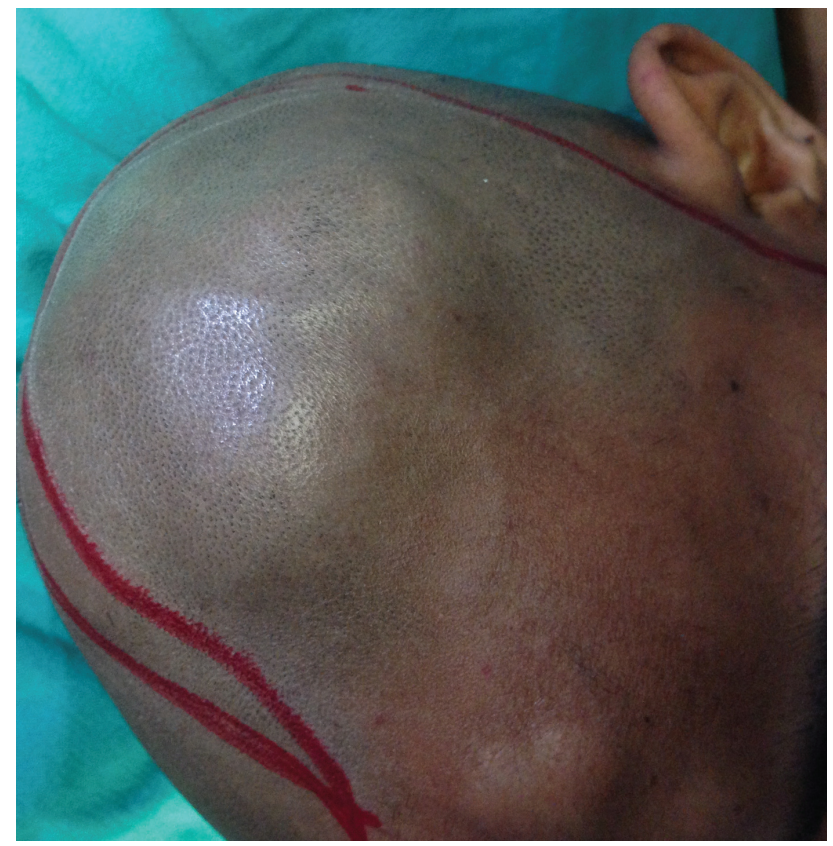

Figure 1. Preoperative image showing frontal and parietal swellings. hepatitis B and C. Computed tomography (CT) scan of the head was performed, revealing a dural-based hyperintense lesion on the frontal and parietal region with subfalcine herniation (Figure 2 and Figure 3) and honeycomb appearance of the involved bone (Figure 4). Ultrasonography of the abdomen revealed no significant lymph nodes.

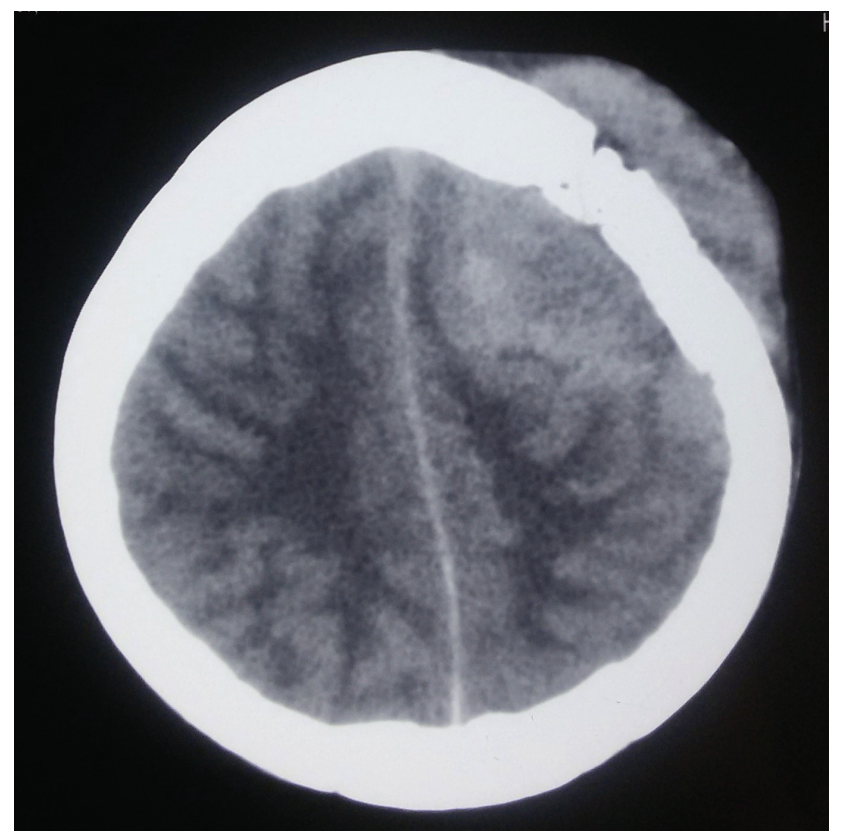

Figure 2. CT image showing hyperintense lesion surrounding the skull bone.

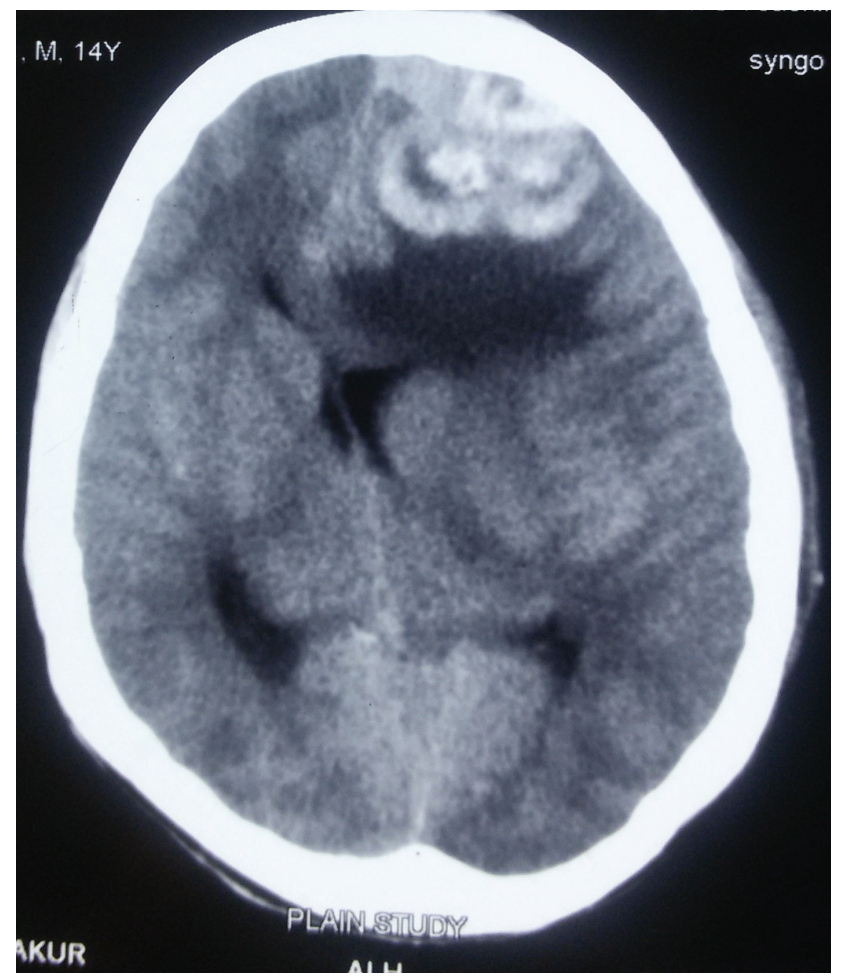

Figure 3. CT image showing the herniation syndrome with gross mass effect. 


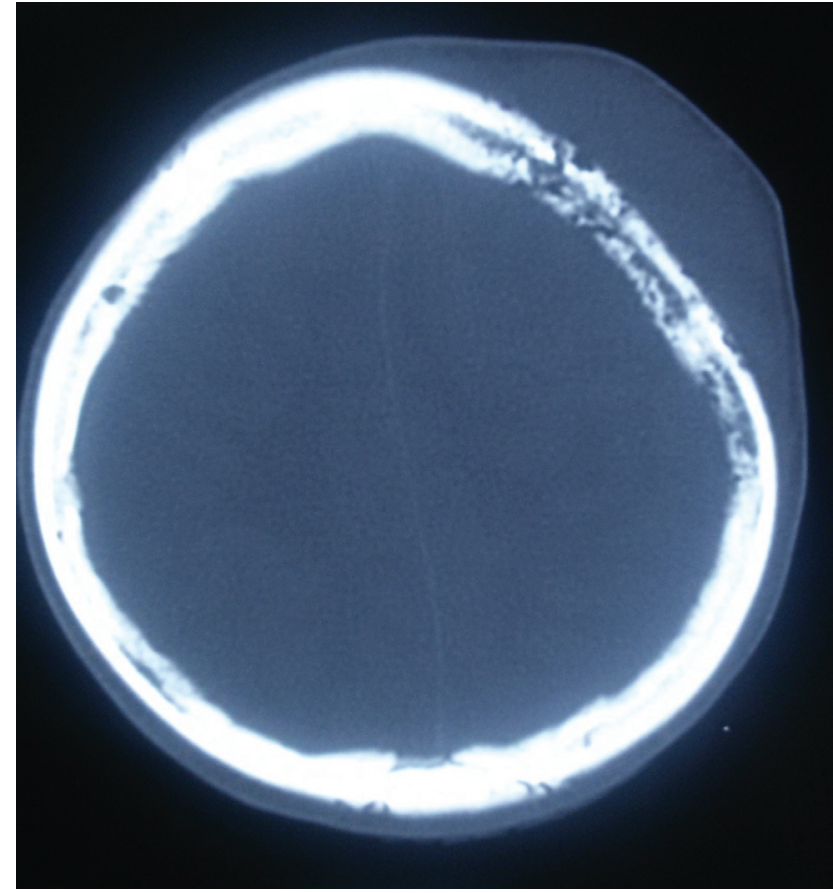

Figure 4. CT image showing the 'Honeycomb' appearance of the involved bone.

Because the child was already herniating, he was started on intravenous dexamethasone ( $4 \mathrm{mg}$ over 8 hours) and a single $100 \mathrm{ml}$ dose of $25 \%$ mannitol was given. Parents were counseled and written consent was taken for operative management. Surgery revealed a duralbased lesion (Figure 5) that was moderately vascular, soft and friable in consistency with involved bone showing a moth-eaten appearance (Figure 6). Both extra- and intra-dural extension (Figure 7 and Figure 8) of the lesion was seen. Scalp lesions, involved bone, and the dural and intradural component were all excised and sent for histopathological (HPE) study. A post-operative scan showed gross excision of the lesions and absence of mass effect (Figure 9). The HPE revealed an immunoblastic variant of diffuse large cell lymphoma (Figure 10).

Postoperatively, the patient improved to GCS 15 . The steroids were slowly tapered off as the mass effect and edema were absent on repeat CT image and also prolonged usage would hamper healing of scalp surgical wound. The patient was thoroughly counseled and then referred for free chemo- and radiation therapy in a government oncology hospital.

\section{Follow-up and outcomes}

The patient's GCS at 2 weeks follow-up was 4 . Patient has been started on chemotherapy and is also advised for regular follow-ups.

\section{Discussion}

Primary dural lymphoma, first described by Oberling $^{5}$, is an exceedingly rare disease entity. Only five cases of primary dural diffuse large B-cell lymphoma have been described so far with a

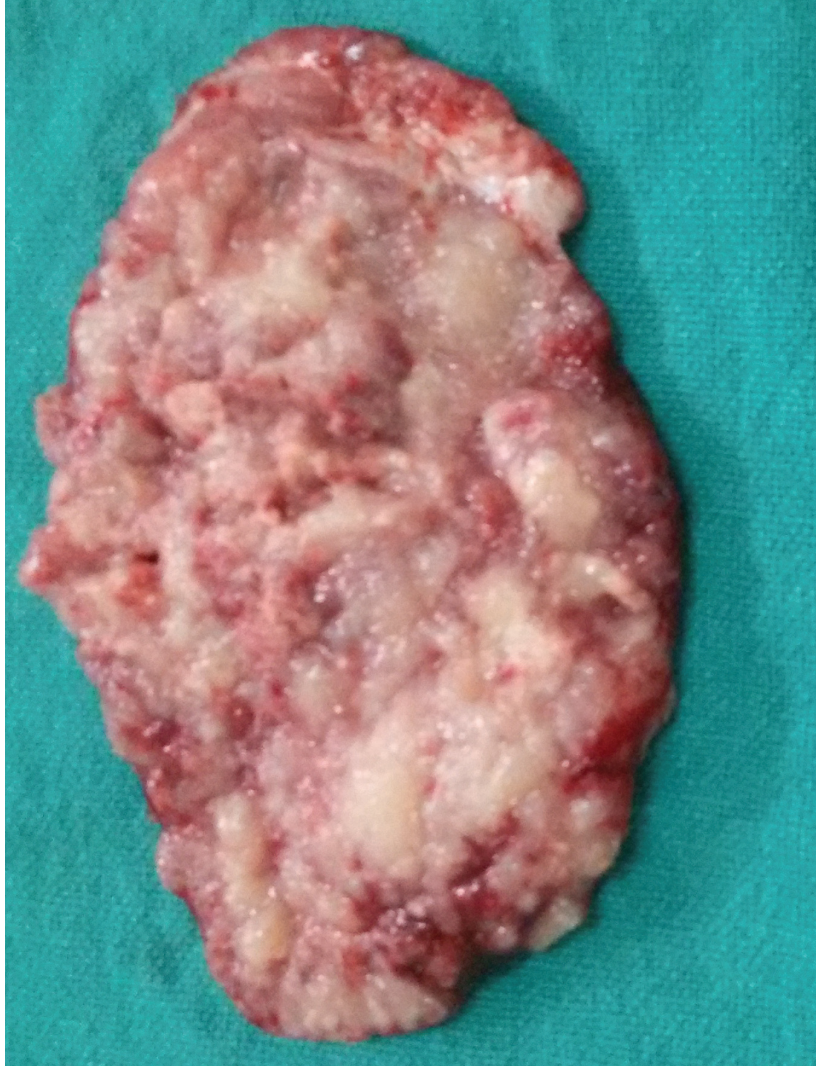

Figure 5. Photograph of the involved dura.

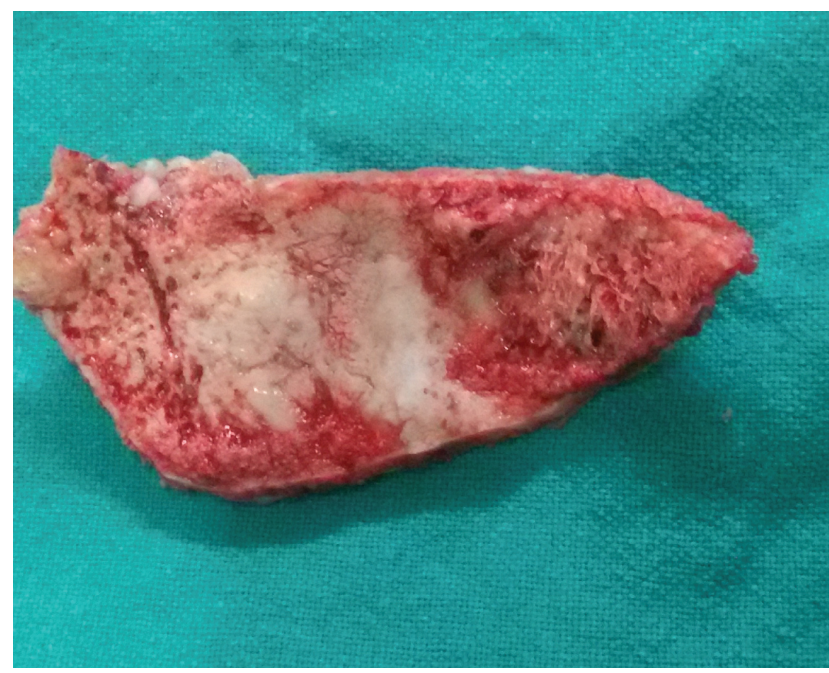

Figure 6. Photograph of the involved bone showing the typical 'honeycomb' appearance.

median age at diagnosis of around 50 years $^{1}$. Trauma, inflammation and viral infection have been postulated as probable causes ${ }^{6}$. The symptoms of the disease are variable and non-specific. The radiological findings are indistinguishable from other dural-based 


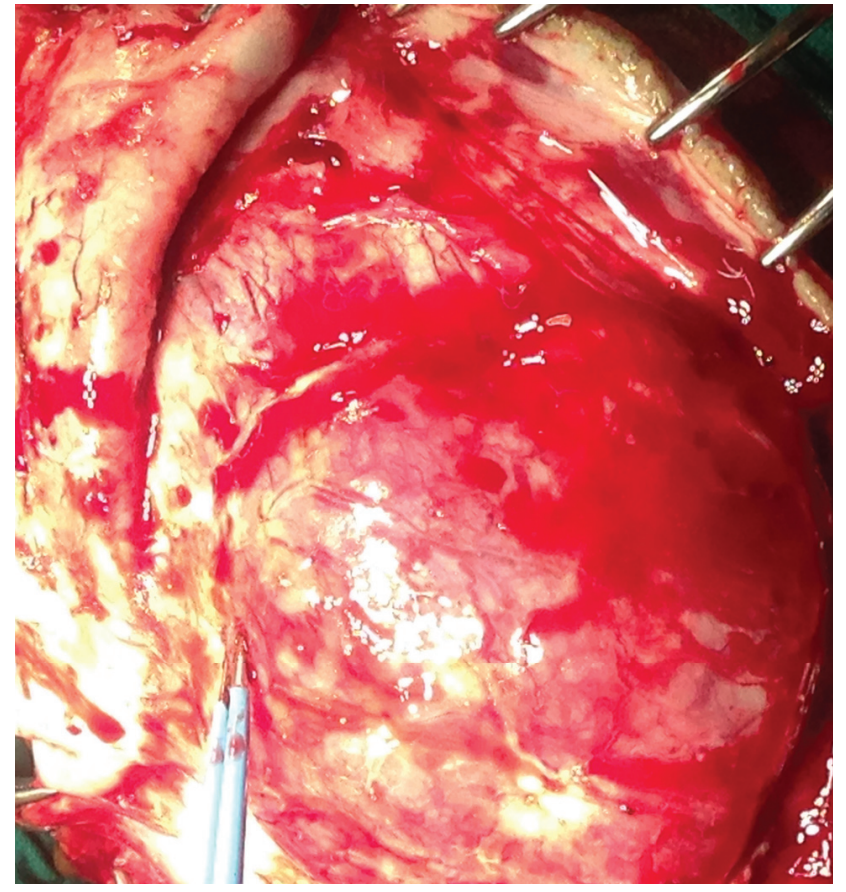

Figure 7. Intraoperative photograph showing the extra-calvarial extension of the lesion.

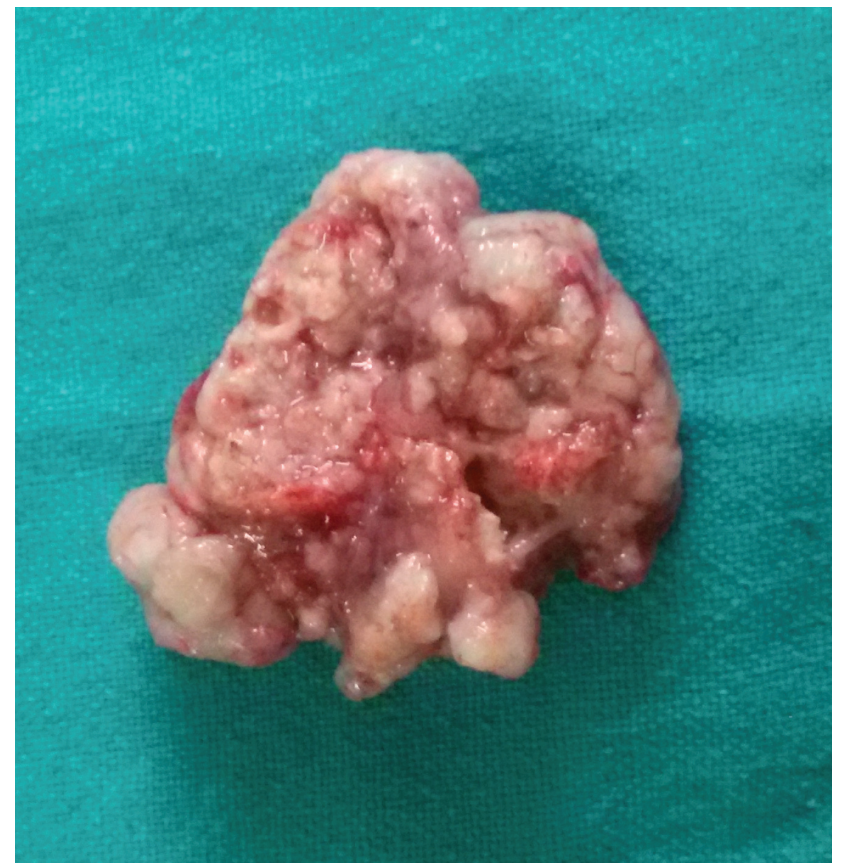

Figure 8. Photograph showing the portion with intradural extension.

lesions such as meningiomas and hemangiopericytomas ${ }^{2}$. Since the prognosis of intracranial DLBCL is favourable ${ }^{4}$, it is important to make a correct and timely diagnosis. Rapid progression of the symptoms, lytic lesions on the bone and restricted diffusion in

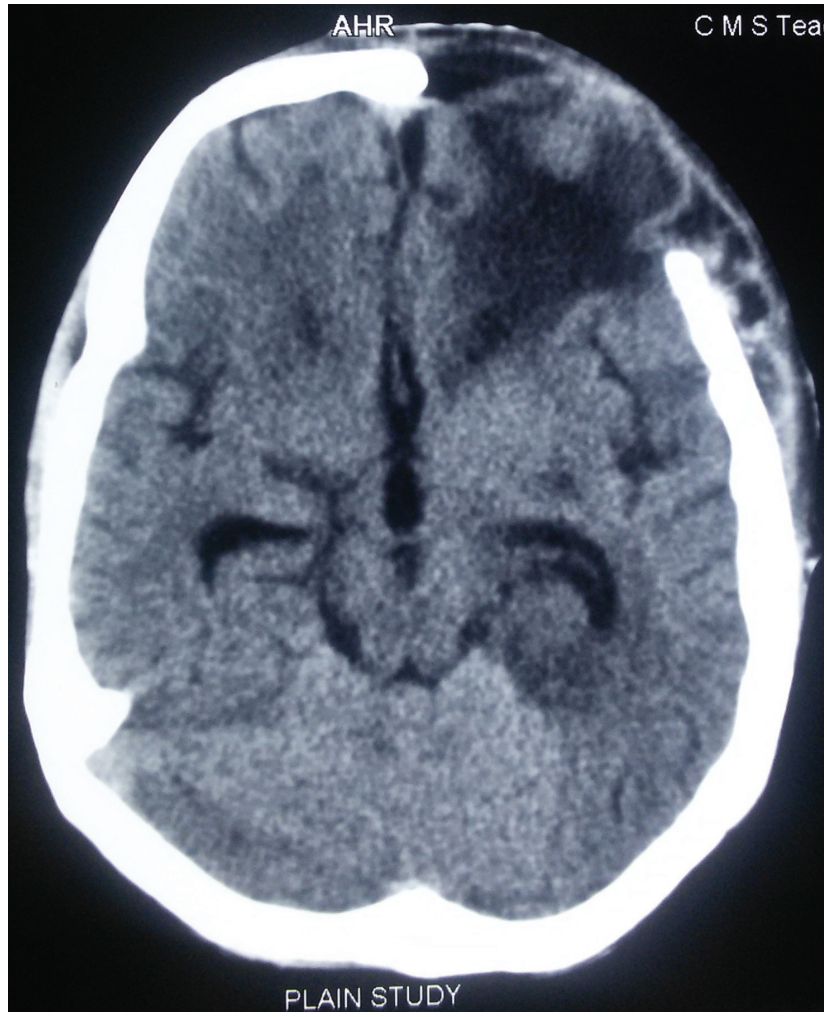

Figure 9. Post-operative CT image showing gross excision of lesion with resolution in mass effect.

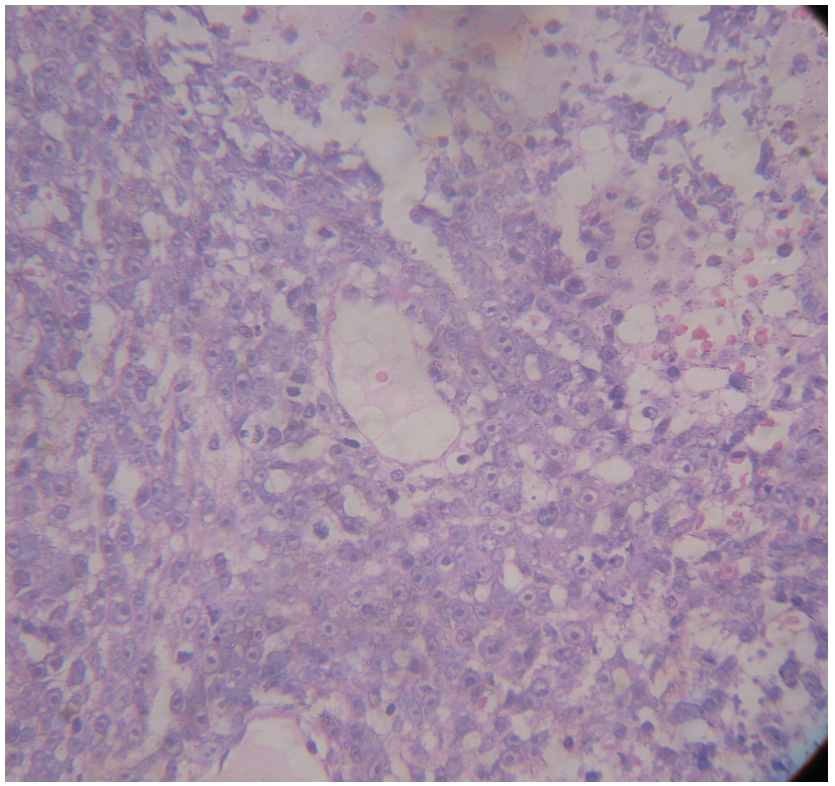

Figure 10. Histopathological slide showing characteristic small round blue cells with prominent nucleoli.

magnetic resonance imaging (MRI) may provide additional clues to the diagnosis. In cases where there are no obvious neurological symptoms, it may be advisable to take a needle biopsy of the scalp 
tumor as described by Ochiai et $a l^{7}$. There has been no consensus on the correct treatment protocol in the management of dural large-cell lymphoma due to a paucity of cases $^{3}$. Previous cases have been treated with tumor resection followed by cyclophosphamide, hydroxy-doxorubicin, oncovin (vincristine) and prednisone (CHOP) with or without rituximab- or methotrexate-based chemo regimes. Additional radiation was also tried in some cases ${ }^{1}$. This case is the youngest age where the entity has been observed and showed good recovery despite initial presentation with herniation syndrome. Therefore, we suggest that maintaining a high index of suspicion and timely intervention is the key to better outcome in the patients.

\section{Consent}

Written informed consent for publication of their clinical details and images was obtained from the father of the patient.

\section{Author contributions}

Dr. Sunil prepared and formatted the paper, Dr. Binod and Dr. Balaji revised the paper and Dr. Cherian approved the final draft. All authors agreed to the final content of the manuscript.

\section{Competing interests}

No competing interests were disclosed.

Grant information

The author(s) declared that no grants were involved in supporting this work.

\section{Acknowledgements}

We would like to acknowledge the Department of Pathology of the College of Medical Sciences for providing us with the histopathological image in preparation of the manuscript.
1. Brito $A B$, Reis $F$, de Souza $C A$, et al:: Intracranial primary dural diffuse large B-cell lymphoma successfully treated with chemotherapy. Int J Clin Exp Med. 2014; 7(2): 456-60.

PubMed Abstract | Free Full Text

2. Johnson MD, Powell SZ, Boyer PJ, et al.: Dural lesions mimicking meningiomas. Hum Pathol. 2002; 33(12): 1211-1226. PubMed Abstract | Publisher Full Text

3. Iwamoto FM, Abrey LE: Primary dural lymphomas: a review. Neurosurg Focus 2006; 21(5): E5.

PubMed Abstract | Publisher Full Text

4. Yamada SM, Ikawa N, Toyonaga S, et al.: Primary malignant B-cell-type dural lymphoma: Case report. Surg Neurol. 2006; 66(5): 539-543.

PubMed Abstract | Publisher Full Text

5. Oberling C: Les reticulosarcomeset les reticuloendotheliosarcomes de la moelleosseuse (sarcomas d'Ewing). Bull Assoc Fr Etude Cancer. 1928; 17: 259-296.

6. Tanimura A, Adachi $\mathrm{Y}$, Tanda M, et al:: Primary peripheral B cell lymphoma, Burkitt-like, of the cranial vault. Acta Haematol. 2005; 113(4): 258-261. PubMed Abstract | Publisher Full Text

7. Ochiai $\mathrm{H}$, Kawano $\mathrm{H}$, Miyaoka $\mathrm{R}$, et al:: Primary diffuse large B-cell lymphomas of the temporoparietal dura mater and scalp without intervening skull bone invasion. Neurol Med Chir (Tokyo). 2010; 50(7): 595-8. PubMed Abstract | Publisher Full Text 


\section{Open Peer Review}

\section{Current Peer Review Status:}

\section{Version 1}

Reviewer Report 24 June 2015

https://doi.org/10.5256/f1000research.6724.r9101

(C) 2015 Thapa A. This is an open access peer review report distributed under the terms of the Creative Commons Attribution License, which permits unrestricted use, distribution, and reproduction in any medium, provided the original work is properly cited.

\section{Amit Thapa}

Kathmandu Medical College, Kathmandu, Nepal

The authors Munakomi et al. have written a nice case report which highlights a rare disease. Diffuse large cell, mixed and immunoblastic lymphomas of B cell origin should be considered together as aggressive lymphomas ${ }^{1}$ which unlike MALT associated primary dural lymphomas are not indolent. However certain facts need to be discussed.

1. Even though rare, this case is not the sixth reported in literature. Other extra axial locations noted are orbit ${ }^{2}$, Meckel cave $^{3,4}$, parasellar ${ }^{5,6}$, zygoma $^{2,7}$, cerebellopontine angle ${ }^{8}$. In 2010, 93 cases with dural based lymphomas with 10 having extra CNS (systemic involvement) had been reported ${ }^{9}$.

2. Tumor immunophenotyping using flow cytometric analysis (CD5, CD10, CD19, and CD20) and by histochemical evaluation of the lymphoid cells is mandatory. These exhibit strong immunoreactivity both to leukocyte common antigen and to B-cell marker (L26). No staining should be noted for chromogranin, synaptophysin, or the epithelial markers AE1 and AE3 ${ }^{1}$.

3. Even though financial restriction is of concern in our country, contrast enhanced CT chest and abdomen should be the protocol to see for lymph node involvement rather than insensitive USG study.

4. This may be a typo error, however to correct the same: Mannitol comes in $20 \%$ and not in $25 \%$ in Nepal.

5. Image (figure 9) show a limited craniotomy causing brain herniation from the site of craniectomy and has been taken at a level lower than lesion previously shown in Figure 2. To allow comparison, it is suggested to provide CT images of same level or plane.

6. Differential diagnosis should include meningiomas, metastases, extradural abscesses with osteomyelitis or extradural hematomas. Clues for diagnosis include a rapid progression of symptoms with permeative growth pattern with large soft tissue component in galeal and extradural compartment, restricted diffusion on MRI, and the presence of bone lytic lesions 
on $\mathrm{CT}$, limited periosteal reaction and an angiographically avascular lesion except for blush or vascular encasement ${ }^{1,10}$.

7. The treatment of choice for primary CNS lymphoma is chemotherapy (Adriamycin containing CHOP protocol) followed by radiation of the involved field and surgical excision is limited to conditions where mass effect is life threatening.

Recognising this entity is important because an early diagnosis and rapid initiation of treatment, in certain cases with sole chemotherapy, is associated with a high response rates and favourable outcome ${ }^{10}$.

\section{References}

1. Galarza M, Gazzeri R, Elfeky HA, Johnson RR: Primary diffuse large B-cell lymphoma of the dura mater and cranial vault. Case report and literature review. Neurosurg Focus. 2006; 21 (5): e10 PubMed Abstract

2. Paige ML, Bernstein JR: Transcalvarial primary lymphoma of bone. A report of two cases. Neuroradiology. 1995; 37 (6): 456-458 PubMed Abstract

3. Abdel Aziz KM, van Loveren HR: Primary lymphoma of Meckel's cave mimicking trigeminal schwannoma: case report. Neurosurgery. 1999; 44 (4): 859-862 PubMed Abstract

4. Artico M, Salvati M, Raco A, Innocenzi G, et al.: Primary Meckel's cave lymphoma. A case and review of the literature. Neurochirurgie. 1992; 38 (6): 368-371 PubMed Abstract

5. Oyama H, Nagane M, Shibui S, Nomura K, et al.: Skull base malignant lymphoma: a case report and review of the literature. Jpn J Clin Oncol. 1992; 22 (2): 131-135 PubMed Abstract

6. Roman-Goldstein SM, Jones A, Delashaw JB, McMenomey S, et al.: Atypical central nervous system lymphoma at the cranial base: report of four cases. Neurosurgery. 1998; 43 (3): 613-615

PubMed Abstract

7. Ng YY, Cook JA, McRae RD: Lymphoma of the zygoma: an unusual cause of unilateral facial swelling. J Otolaryngol. 1990; 19 (5): 315-318 PubMed Abstract

8. Berciano J, Jimenez C, Figols J, Ferreres JC, et al.: Primary leptomeningeal lymphoma presenting as cerebellopontine angle lesion. Neuroradiology. 1994; 36 (5): 369-371 PubMed Abstract

9. Matmati K, Matmati N, Hannun YA, Rumboldt Z, et al.: Dural MALT lymphoma with disseminated disease. Hematology Reports. 2010; 2 (1): e10 PubMed Abstract | Free Full Text | Publisher Full Text 10. Brito $A B C$, Reis $F$, de Souza $C A$, Vassallo J, et al.: Intracranial primary dural diffuse large B-cell lymphoma successfully treated with chemotherapy. Int J Clin Exp Med. 2014; 7 (2): 456-460 PubMed Abstract | Free Full Text

Competing Interests: No competing interests were disclosed.

I confirm that I have read this submission and believe that I have an appropriate level of expertise to confirm that it is of an acceptable scientific standard.

Reviewer Report 15 May 2015

https://doi.org/10.5256/f1000research.6724.r8460 
(C) 2015 Gao G. This is an open access peer review report distributed under the terms of the Creative Commons Attribution License, which permits unrestricted use, distribution, and reproduction in any medium, provided the original work is properly cited.

\section{Guo-Yi Gao}

Department of Neurosurgery, Renji Hospital, Shanghai Institute of Head Trauma, Shanghai, China

Primary dural lymphoma is the disease to most neurosurgeons and this case report provided details of a young patients' clinical treatment including diagnosis, surgery, and following chemotherapy and radiotherapy choices. It is worth indexing to improve the management of dural lymphoma.

Competing Interests: No competing interests were disclosed.

I confirm that I have read this submission and believe that I have an appropriate level of expertise to confirm that it is of an acceptable scientific standard.

The benefits of publishing with F1000Research:

- Your article is published within days, with no editorial bias

- You can publish traditional articles, null/negative results, case reports, data notes and more

- The peer review process is transparent and collaborative

- Your article is indexed in PubMed after passing peer review

- Dedicated customer support at every stage

For pre-submission enquiries, contact research@f1000.com 